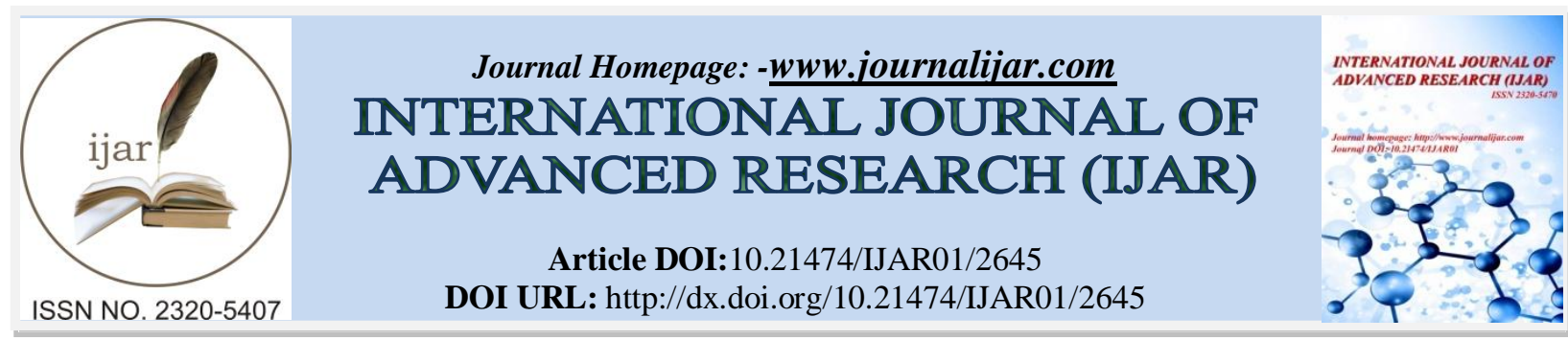

RESEARCH ARTICLE

\title{
AN EMPIRICAL ANALYSIS OF THE FACTORS AFFECTING EFFICIENCY OFNIGRIA'S PUBLIC UNIVERSITIES.
}

\section{Mohammad Adamu,Jan-Jan Soon and SitiAznor Ahmad.}

Department of Economics and Agribusiness, School of Economics, Finance and Banking, Universiti Utara Malaysia 06010 Sintok, Kedah. Malaysia.

\section{Manuscript Info}

\section{Manuscript History}

Received: 30 October 2016

Final Accepted: 29 November 2016

Published: December 2016

Key words:-

Efficiency; University; DEA; Inputs; Outputs.

\section{Abstract}

The factors that influence the efficiency or otherwise of universities are often been overlooked by most of the university efficiency studies. Those factors are not included in the inputs-outputs analysis and are sometimes referred to as external or environmental factors. The massive dependent on government for university's fund in Nigeria causes some external factors which are affecting the Nigerian public universities especially staff strike actions. Therefore, this paper uses DEA which is the mostly accepted technique of analyzing efficiency of public institutions and universities in order to investigate the technical efficiency of 18 public universities in Nigeria from $2007 / 2008$ to $2011 / 2012$ academic years. Thispaper forges ahead to the second stage DEA to determine the effect of external factors on the efficiency of those universities using the tobit model. The DEA result shows very low efficiency scores of the universities where only 2 universities are found to be technically efficient for the whole 5 years observed and 6 universities have never attained efficiency in any of the years. At $5 \%$ level of significance, the tobit regression outcome shows that financing the university has a negative effect on the inefficiencies of the universities, thereby suggesting a boost of the government funding based on performance. Also, size of the universities and staff strike actions both have positive significant effect for been inefficient but with little magnitude. Larger universities tend to be more inefficient whilestaff strike actions increase the inefficiency rate of the universities. Therefore, funding the universities can tackle the inefficiency caused by strike actions and the universities should be given some autonomy. Also, the universities should generate internal source of funding to complement those fund coming through the government.

Copy Right, IJAR, 2016,. All rights reserved.

\section{Introduction:-}

The developed countries have massive and concrete higher educational institutions while the under-developed countries continuously lack the appreciation for the need of taking it seriously. Education has been pushed by the developed countries to the level of governancewhile in under-developed countries is still at the basic foundation. For example, publicuniversitiesin Nigeria have high dependence on the governments for their financial resourceswhile 
tuition fees are often negligible or non-existent.However, the percentage allocation to the education sector does not meet the 25 percent budgetary allocation recommended by the UNESCO (Ajaiya and Usman, 2010). The education budget in Nigeria and most countries in the Sub-Saharan Africa are typically allocated as follows: Primary $40 \%$, Secondary 30\%, and Higher Education 20\% (World Bank, 1995).However, the efficient use of the government finance in universities has increasingly been questioned especially the per-unit cost of producing a graduate.

Due to the financial botheration in public universities merging with growth of students' intake in both undergraduate and postgraduate levels and increase in faculties and university size. It becomes harder for the universities to efficiently run their programmes effectively. Hence, the limited finance by the government causes denial to some benefits of the staff, curtailment of research funding, cutbacks in staff development programmes which eventually causesstrike actions by the staff of universities, table 1 shows the strike frequency in the past 16 years.

Table 1:- University Strike Actions

\begin{tabular}{|l|l|}
\hline YEAR & PERIOD LENGTH \\
\hline 1999 & Five (5) Months \\
\hline 2000 & Nil \\
\hline 2001 & Three (3) Months \\
\hline 2002 & Two (2) Weeks \\
\hline 2003 & Four (4) Months \\
\hline 2004 & Two (2) Months \\
\hline 2005 & Days \\
\hline 2006 & Days \\
\hline 2007 & Three (3) Months \\
\hline 2008 & One (1) Weeks \\
\hline 2009 & Four (4) Months \\
\hline 2010 & $>$ Five (5) Months \\
\hline 2011 & One (1) Month \\
\hline 2012 & Two (2) Months \\
\hline 2013 & Five (5) Months \& Two(2) Weeks \\
\hline Source: Extracted from Anaba (2013) \\
\hline
\end{tabular}

Therefore, the longer and frequent strike actions, longer period before graduation and infrastructural decay in the Nigerian universities, ginger many Nigerians to fly out of the country with curiosity and intention of getting better education abroad through self-sponsorship or scholarships which can be a leakage to Nigeria's economy. This is to show that there are other factors which affect efficiency of public universities outside the main efficiency's inputoutput variables and they are referred as environmental or external factors affecting efficiency in the literature.

Therefore, this papertries to analyse the efficiency of Nigerian public universities and the factors affecting the efficiency of the universities using data envelopment analysis DEA and second-stage DEA respectively. The subsequent sections of this paper presents the conceptual framework; literature review of recent and relevant studies; methodology and data presentation where the inputs and outputs used in the study are defined as well as the variable factors outside the input and output; then results presentation and overall discussion; and finally, concluding remarks and policy recommendation.

Conceptual Framework and Data Envelopment Analysis (DEA):

Efficiency measurement is one element that determines universities' performance especially public universities using the inputs and outputs. It can be done through maximisation of output or minimisation of cost which literature refers as the output orientation DEA or input oriented DEA respectively. Sherman and Gold (1985) defines efficiency as the capability to deliver the outputs or services with the least resource level needed. Farrell (1957), who has the credit of pioneering the estimation of productive efficiency, perceives it as the significance of measuring the degree to which outputs can be expanded through greater efficiency without utilising extra input resources. Therefore,this paper uses the M. J. Farrell's efficiency concept to analyse the efficiency of Nigerian public universities. According to the concept, efficiency assesses a relative measurementwhich describes the relationship with respect to maximum value between inputs and outputspossible toobtain in given technological conditions (Farrell 1957). Farrell explains that the efficiency constitutes two segments: technical efficiency and allocative efficiency. Technical Efficiency (TE) mirrors the capacity to acquire maximum output from a given 
amount of inputs. Henceforth, technical inefficiency means the inability or failure to utilise the available inputs in producing the highest feasible and attainable output from those inputs.Allocative Efficiency (AE) shows the capacity to utilise inputs in ideal extents (optimal proportions), given their respective prices. Allocative inefficiency accordingly emerges when it is unable to exploit utilising substitutable less expensive inputs to cause the least cost of production. Therefore, efficiency may be a joined impact of TE and AE. This joined impact is referred to as economic efficiency (EE), and is measured as a product TE and AE.

$$
\mathrm{EE}=\mathrm{TE} \times \mathrm{AE}
$$

Farrell's productivity concept is basically on relative efficiency measurement method of Data Envelopment Analysis (DEA) developed by A. Charnes, W. W. Cooper and E. Rhodes (Charnes et al. 1978). In this method, technical efficiency (E) of a university, called Decision Making Unit (DMU) is the ratio of a weighted sum of the outputs to the weighted sum of the inputs. Figure 1 shows the framework where the input variables are converted and processed by the universities in order to produce outputs.

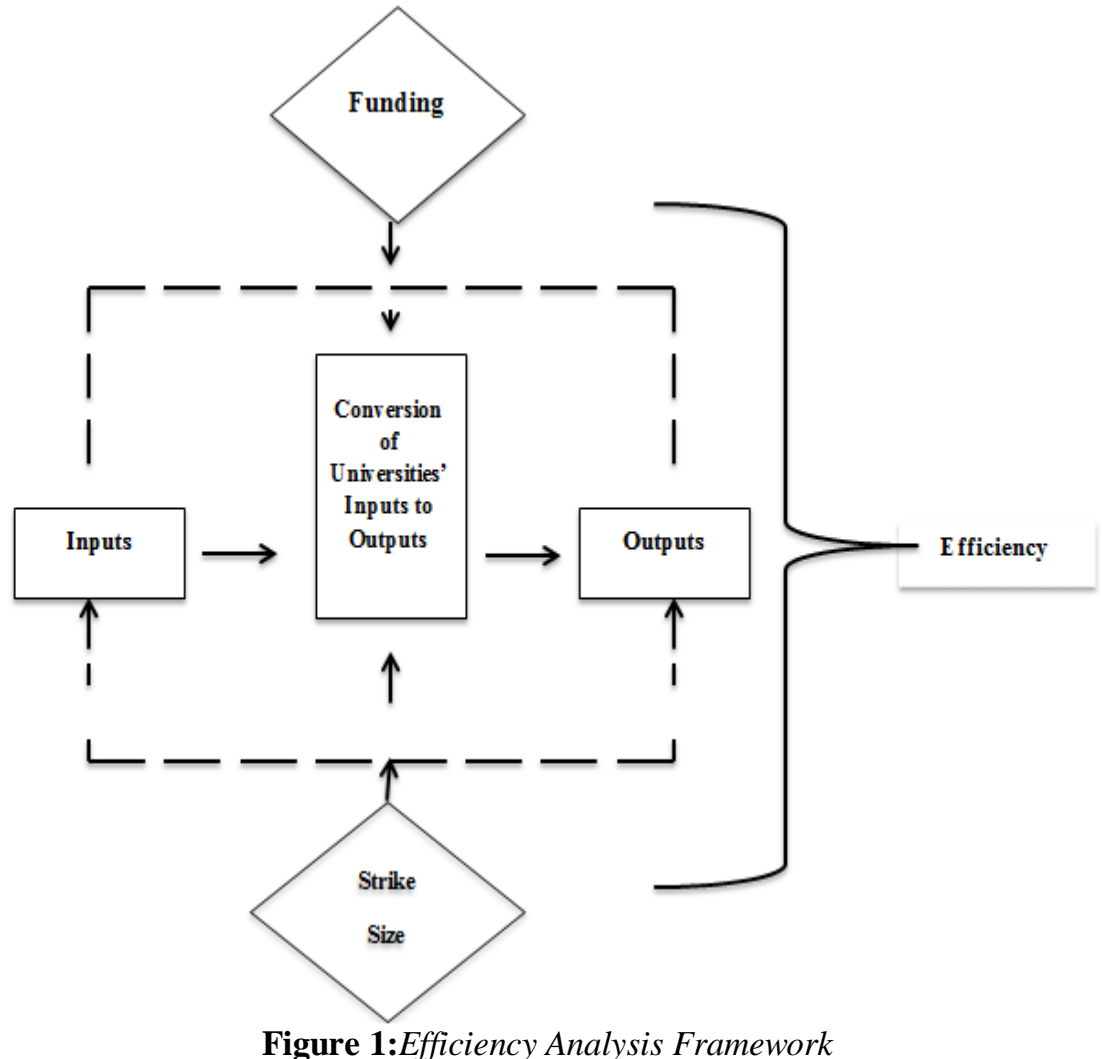

Source: Derived by authors based on Chu and Lim (1998)

The external factors or environmental factors are not within the inputs or outputs but still affect the efficiency of the universities, which are funding, size of the university and strike actions by the university staff in Nigerian public universities.

\section{Literature Review:}

The popular non-parametric technique used in efficiency analysis is the Data Envelopment Analysis (DEA) and studies with that method include (Coelli, 1996b; Worthington, 2001; Avkiran, 2001; Abbott and Doucouliagos, 2003; Casu\&Thanassoulis, 2006; Johnes, 2006; Kantabutra and Tang, 2010). Using the same method, Worthington and Lee (2008) measure the efficiency of universities during the period 1998-2003. Johnes (1996), Athanassopoulos and Shale (1997) and Flegg et al. (2004) examines efficiency of universities in UK with same methodology.

DEA is the most appropriate technique for public institutions like the universities given the possession of multiple inputs and outputs, Katharaki and Katharakis (2010) consistently and reliably evaluate the technical efficiency of 20 public universities in Greece using resources in two main activities; teaching and research. Their results show inefficiency in terms of human resourcesmanagement, however, it shows clear opportunity to increase research 
activity, likewise research income. Additionally, Avkiran (2001) used DEA in analysing the relative efficiency of universities in Australia focusing on three models which are; overall performance model, performance on delivery educational service and performance on fee-paying enrolments. Efficiency difference between private and public universities in Chile is examined by Ramirez-Correa et al. (2012) using DEA where the outcomes reveal insignificant statistical differences between the universities. Kuah and Wong (2011) use 30 public universities in Asia and find that the universities in Asia focus more on research than teaching because the universities are found to be more efficient in research than teaching. Out of the 30 universities, only 1 university is found to be efficient both in teaching and research activities. 3 are said to be efficient in teaching only, and 11 are found to be efficient in research activities only. Nazarko and Saparauskas (2013) describe a comparative efficiency study about 19 public universities of technology and conclude that there are diversifications regarding efficiency performance in those Polish universities of technology.

Aziz et al. (2013) use DEA to evaluate the relative efficiency of 22 academic departments of a public university in Malaysia with four different dimensional models where input-output combinations are differentially defined. They finally explain that social science base department performs efficiently better than science based. They further explain those different combinations of input-output result to different efficiency levels based on sensitivity analysis.Pietrzak et al. (2016)empirically investigate 33 specialised social science faculties of different public universities in Poland for the academic year of 2013/2014 using DEA. They finally present 9 faculties to be full efficient with overall efficiency average index of 0.72.In sub-Saharan Africa, only Taylor and Harris (2004) evaluate 21 South African public universities for a period of 4 years and 10 universities are found to be efficient.

This paper is different from previous studies because significant number of existing studies is exclusively on the evaluation of efficiency levels using the different models and variable specifications. Therefore, this paper specifically contributes a step further and makes some links between the universities' efficiency and funding levels, university size and most importantly strike actions of university staff. The few studies that explore the relationship between efficiency and funding in universities, example, Tochkov et al. (2012) find efficiency not to be a significant determinant of the amounts of subsidy allocated to a university, and efficiency and funding are found to be negatively related. In the study of Caballero et al. (2004) show that the allocation of budgetary funds for hiring teaching staff among departments at the University of Malaga in Spain improved the average technical efficiency with respect to teaching which is in contrast with Tajnikar and Debevec (2008) study which reported that inefficient departments within the University of Ljubljana in Slovenia received disproportionately more funds than efficient ones.

The existing literature demonstrates differences in the relationship between size and efficiency. A related study by Berger, Hunter and Timme (1993) revealed that the positive relation between efficiency and size may not be visible as factors signifying so are not yet conclusive.Avkiran (1999) in Australia made a panel analysis from 1986-1995 and finds the relationship between size and efficiency not significant, while Reda and Isik (2006) find a positive and significant relationship. Isik and Hassan (2002) study indicate that size is negatively related to efficiency. Although there are higher costs recorded for the small firms, their technical and scale efficiency are better compared to their larger counterparts.

Strike activity is conceived as an impression of "worker militancy" and the Hicksian notion of strike is seen as bargaining "miscalculations". Hicks' formulation, on the other hand, is most accurately applied to strikes at contract renegotiations, which are expected to have effect on productivity. Maki (1983) used a pooled cross-section time series data on twenty countries and shows that increased strike activity generally results in lower productivity growth. On a contradictory note, Dickerson et al. (1997) find a negligible net impact of strike action on productivity and the same result by Maki, (1986) which discovered some weak evidence of the hypothesised opposite relationship between loss of output and strikes' volume utilising bivariate transfer function.

Secondly,this paper is differentiated from the other studies with the exception of Taylor and Harris (2004)allprevious studies evaluated universities in the developed countries of NorthAmerica, Australia, Europe, and Asia where university funding is smoothercompared to African countries and especially, Nigeria where the funding issues cause longer and incessant strike actions by the university staff. 


\section{Methodology and Data Presentation:-}

The widely known method of non-parametric technique which is largely used in efficiency studies of higher education institutions or universities, including other non-profit oriented organisations is the Data Envelopment Analysis (DEA). In this model, specification of a priori functional form is not required and this makes the approach the most appropriate.

In DEA models, specification of inputs and outputs is the first important stage to achieve any efficiency evaluation and there is no conclusive standard to guide the inputs and outputs determination and selection. However, consideration must be given to the main purpose of having a university and they are; research and teaching. In this paper, 3 inputs and 2 outputs are usedwhich are expenditure, student-teacher ratio, total enrolment, publications and graduates respectively as presented by table 2 and takingintoaccounttheimpactofthe external or environmental factors; funding, size and strike, whichremainsoutofuniversity's control.

Table 2: Input-Output variable

\begin{tabular}{|rl|r|}
\hline Inputs & Outputs \\
\hline 1) & Expenditure EXP & 1) Publications PUB \\
\hline 2) & Student/Teacher ratio STR & 2) Graduates NOG \\
\hline Total Enrolment TNE & \multicolumn{2}{|l|}{} \\
\hline
\end{tabular}

Source: Coined by authours.

On that note, this paper adopts the output-oriented DEA linear programming model developed by Charnes et al. (1978) and Anderson et al. (2007) also adopted it in analysing the U.S universities. However, McMillan and Datta (1998) clarify that the outcomes of DEA analysis are not sensitive to orientation; input or output. Therefore, this paper strictly adopts the output-oriented DEA.

$$
\begin{gathered}
\operatorname{Max}_{\beta_{k, \lambda}} \beta_{k} \\
\text { S.t } \sum_{j=1}^{n} Y_{r, j} \lambda_{j} \geq \beta_{k} Y_{r, k} \\
r=1, \ldots, s \\
\sum_{j=1}^{n} X_{i, j} \lambda_{j} \leq X_{i, j} \ldots \text { Equation (1) } \\
i=1, \ldots, m \\
\sum_{j=1}^{n} \lambda_{j}=1 \\
\lambda \geq 0
\end{gathered}
$$

The $\underset{\beta_{k, \lambda}}{\operatorname{Max}} \beta_{k}$ is defined as efficiency of the universities to be maximised which is measuring the distance to efficiency frontier. $\sum_{j=1}^{n} Y_{r, j} \lambda_{j} \geq \beta_{k} Y_{r, k}$ is signifying the act of producing more output while $\sum_{j=1}^{n} X_{i, j} \lambda_{j} \leq X_{i, j}$ is constrain of using no more inputs. Allowing for variable return to scale by requiring that each university be compared against a full university made up of parts of one or more universities is denoted by 
$\sum_{j=1}^{n} X_{i, j} \lambda_{j} \leq X_{i, j}$ while $\sum_{j=1}^{n} \lambda_{j}=1$ shows that no negative value is entertain, meaning negative values of the universities can never be used for analysis. The expression $\beta_{k}$ is the efficiency to be maximised, and the value of $\mathrm{X}_{\mathrm{i}, \mathrm{j}}$ explains the amount of the $\mathrm{i}^{\text {th }}$ input going to be utilised by $\mathrm{j}^{\text {th }}$ university. That means 3 in this paper because we consider 3 inputs. The outputs are given by $\mathrm{Y}_{\mathrm{r}, \mathrm{j}}$ for $\mathrm{r}^{\text {th }}$ output of the $\mathrm{j}^{\text {th }}$ university. $\mathrm{K}=1 \ldots, 18$ which is the universities considered to be analysed in this paper. The fundamental decision variables are $\lambda_{\mathrm{j}}$ which is the weight given to $\mathrm{DMU}_{\mathrm{j}}$ in its efforts to dominate $\mathrm{DMU}_{0}$ or how much $\mathrm{j}^{\text {th }}$ university is utilised in setting a performance target for university K.

The inefficientallocation of government funds for the public universitieswhich created strike actions and other problems in the public universities call for policy measures that willimprove the performance of the public universities and reform the budgetary distribution. For this reason, thispaper goes further to identify the factors affecting the efficiencypublic universities in Nigeria using the second-stage DEA with the aid of tobitregression analysis. The tobit model is the most common in theliterature when explaining efficiency and is used by, for example, Kirjavainen and Loikkanen (1998) and Kounetas et al. (2011) for universities in Greece. The tobit model is as follows;

$$
E F F_{i}= \begin{cases}0 & \text { if } 0 \geqslant z_{i} \beta_{i}+\varepsilon_{i}, \\ z_{i} \beta_{i}+\varepsilon_{i} & \text { if } 0<z_{i} \beta_{i}+\varepsilon_{i}<1 \\ 1 & \text { if } 1 \leqslant z_{i} \beta_{i}+\varepsilon_{i} .\end{cases}
$$

...Equation (2)

The model shows the relative efficiency scores obtained from DEA; the vector $z_{i}$ represents the variables which affect university (DMU) efficiency in reality while the vector $\beta$ is the coefficient to be estimated. Using this process, the paper makes effort to show the variability of the estimated technical efficiency scores with range of variables under tobit framework. This will show the effects of external institutional variables on efficiency of universities (Kempkes and Pohl, 2008). Equation 2 is further specified as;

$E F F_{i, t}=a_{0}+b_{1}(E X P)_{i, t}+b_{2}(U N S)_{i, t}+b_{3}(S T R)_{i, t}+U_{i, t} \quad \ldots$ Equation (3)

The $U_{i t}$ is the error term, $a_{0}$ is the autonomous variable and $\mathrm{b}_{1}-\mathrm{b}_{3}$ are the coefficients of the independent variables; Expenditure (EXP) measured by total fund spent, University size (UNS) measured by number of faculties, and Strike (STR) which is measured as a dummy variable as $1=$ strike and $0=$ no strike.

This paper systematically samples 18 public universities which are known to as the "First" and "Second" generation universities in Nigeria.For that purpose, data are collected from National Universities Commission (NUC) and its publications, National Bureau of Statistics (NBS) and its Annual Abstracts, and the respective universities' websites.

\section{Findings andDiscussion:-}

The application of the DEA model for the 18 public universities in Nigeria from 2007/2008 to 2011/2012 academic years, the relative technical efficiency scores of the universities are summarised in Table 3 which is done using the DEAP software (Coelli, 1996a) and the universities are represented by $\mathrm{DMU}_{1}$ to $\mathrm{DMU}_{18}$.

Table 3: Technical Efficiency Estimates 2007/08-2011/12

\begin{tabular}{|c|c|c|c|c|c|c|}
\hline \multirow[b]{2}{*}{ DMU } & \multicolumn{6}{|c|}{ Technical Efficiency (TE) } \\
\hline & $07 / 08$ & & & & & $11 / 12$ \\
\hline $\mathrm{DMU}_{1}$ & 1.000 & 1.000 & 1.000 & 1.000 & 1.000 & \\
\hline $\mathrm{DMU}_{2}$ & 1.000 & 0.830 & 0.986 & 0.733 & 0.821 & \\
\hline $\mathrm{DMU}_{3}$ & 0.791 & 0.695 & 0.839 & 0.717 & 0.844 & \\
\hline $\mathrm{DMU}_{4}$ & 0.881 & 0.968 & 0.944 & 0.710 & 0.865 & \\
\hline $\mathrm{DMU}_{5}$ & 0.889 & 0.870 & 1.000 & 0.882 & 1.000 & \\
\hline $\mathrm{DMU}_{6}$ & 0.659 & 0.725 & 0.842 & 0.603 & 0.619 & \\
\hline $\mathrm{DMU}_{7}$ & 1.000 & 1.000 & 1.000 & 1.000 & 1.000 & \\
\hline $\mathrm{DMU}_{8}$ & 1.000 & 0.967 & 0.999 & 0.875 & 1.000 & \\
\hline $\mathrm{DMU}_{9}$ & 0.797 & 0.968 & 0.854 & 0.802 & 0.948 & \\
\hline $\mathrm{DMU}_{10}$ & 0.804 & 0.962 & 0.936 & 1.000 & 1.000 & \\
\hline $\mathrm{DMU}_{11}$ & 1.000 & 1.000 & 0.723 & 0.675 & 1.000 & \\
\hline
\end{tabular}




\begin{tabular}{|c|c|c|c|c|c|}
\hline $\mathrm{DMU}_{12}$ & 0.839 & 0.932 & 0.882 & 0.825 & 0.468 \\
\hline $\mathrm{DMU}_{13}$ & 0.715 & 0.862 & 0.746 & 0.748 & 1.000 \\
\hline $\mathrm{DMU}_{14}$ & 0.971 & 0.922 & 0.703 & 0.989 & 0.889 \\
\hline $\mathrm{DMU}_{15}$ & 1.000 & 1.000 & 1.000 & 0.849 & 0.985 \\
\hline $\mathrm{DMU}_{16}$ & 0.990 & 0.892 & 1.000 & 0.881 & 1.000 \\
\hline $\mathrm{DMU}_{17}$ & 1.000 & 0.797 & 1.000 & 1.000 & 1.000 \\
\hline $\mathrm{DMU}_{18}$ & 0.947 & 0.827 & 0.841 & 1.000 & 0.999 \\
\hline Mean & 0.905 & 0.901 & 0.905 & 0.849 & 0.913 \\
\hline
\end{tabular}

Table 3 showed the result of the DEA efficiency scores and 2DMUs are found to be fully efficient $\left(\mathrm{DMU}_{1}\right.$ and $\mathrm{DMU}_{7}$ ) for the whole five academic years 2007/08 to 2011/12 and serve as the benchmark for the other DMUs. However, $\mathrm{DMU}_{3}, \mathrm{DMU}_{4}, \mathrm{DMU}_{6}, \mathrm{DMU}_{9}, \mathrm{DMU}_{12}$ and $\mathrm{DMU}_{14}$ have never attained efficiency score of 1.000 in any of the 5 years under observation.

The relationship between the universities' efficiency and the independent variables, i.e., expenditure, size and strike is explained by the tobit regressionresult.

Table 4: Tobit Regression Estimates

\begin{tabular}{|c|c|c|c|}
\hline \multirow{2}{*}{$\begin{array}{l}\text { Independent } \\
\text { Variable }\end{array}$} & \multicolumn{3}{|c|}{$\begin{array}{l}\text { Technical Efficiency (TE) } \\
\text { (90 Obs.) }\end{array}$} \\
\hline & Coef. & Prob. & $\mathbf{R}^{2}(0.3881)$ \\
\hline Constant & 0.950061 & 0.0000 & \\
\hline Exp. & -1.421115 & 0.0162 & \\
\hline Uns. & 0.000730 & 0.0224 & \\
\hline Str. & 0.024042 & 0.0318 & \\
\hline
\end{tabular}

The variables are all statistically significant at 5\% level.Inefficiency of universities in Nigeria is negatively affected by expenditure. The findingsseemto be logical because of the funding issues by the government. While as, the university size and strike are positively related with inefficiency but in a small magnitude.

\section{Conclusion:-}

Universities are institutions that required serious attention due to their immense importance in nation building. Thispaper estimatedthe efficiency scores of Nigerian public universities within the period 2008-2012. Data Envelopment Analysis DEA is used for benchmarking the universities within the range of study.

DEA is a kind of input and output analysis; therefore, thevariable inputs usedare the university total expenditure, student/teacher ratio and university total enrolments while the variable outputs are the university publications and the total number of graduates, all per academic session. The analysis from DEA forthe efficiency of the sampled universities showed low efficiencyscores.

The paper forges ahead to the second stage DEA to determine the effects of environmental factors on the efficiency with a tobit model.The outcomes show that financing the university has a negative significant effect on the inefficiencies of the universities, thereby suggesting a boost of the government funding based on performance. Another important factors influencing the inefficiency performance of the universities are size of the universities and strike actions which both have positive effects on the inefficiency. Larger universities tend to be more inefficient and strike actions increase the inefficiency rate of the universities. Unnecessary increase in number of faculties and departments do not increase efficiency, except with all the required funds, adequate qualified staffs, and sufficient facilities.

Government is the main source of fund for the Nigeria's public universities, therefore funding the universities can tackle the inefficiency caused by strike actions because the university staffs usually go on strike due to inadequate funding by the government. Also, managing universities is same like managing other organisations; hence autonomy to the universities is equally important toward improving their efficiencies.

\section{References:-}

1. Abbott, M., \&Doucouliagos, C. (2003). The efficiency of Australian universities: a data envelopment analysis. Economics of Education review,22(1), 89-97. 
2. Abdulkareem, A. Y., \&Oyeniran, S. (2011). Managing the performance of Nigerian universities for sustainable development using data envelopment analysis. International Journal of Academic Research in Business and Social Sciences, $1,1$.

3. Agasisti, T. \&Johnes, G. (2009). Beyond frontiers: Comparing the efficiency of higher education decisionmaking units across more than one country. Education Economics, 17(1), 59-79

4. Agasisti, T. \&P'erez-Esparrells, C. (2010).Comparing efficiency in a cross-country perspective: the case of Italian and Spanish state universities.Higher Education, 59, 85-103.

5. Ajaiya M. A. and Usman A. (2010). Budgetary allocations and sectoral contributions to economic development in Nigeria.Interdisciplinary Journal of Contemporary Research in Business, 1(10), 83-94.

6. Anaba, A. (2013, July 4). ASUU strikes again: a trip down the ASUU strike lane since 1999 in 10 charts. The Scoop. Retrieved from http://www.thescoopng.com/asuu-strikes-again-a-trip-down-the-asuu-strike-lane-since1999-in-10-charts/

7. Anderson, T. R., Daim, T. U., \& Lavoie, F. F. (2007).Measuring the efficiency of university technology transfer. Technovation, 27(5), 306-318.

8. Athanassopoulos, A. D. \& Shale, E. (1997).Assessing the comparative efficiency of higher education institutions in the UK by means of data envelopment analysis.Education Economics, 5(2), 117-134.

9. Aubyn, M. S., Garcia, F., \&Pais, J. (2009). Study on the efficiency and effectiveness of public spending on tertiary education (No. 390). Directorate General Economic and Monetary Affairs (DG ECFIN), European Commission.

10. Avkiran, N. K. (1999). The evidence on efficiency gains: The role of mergers and the benefits to the public. Journal of Banking \& Finance, 23(7), 991-1013.

11. Avkiran, N. K. (2001). Investigating technical and scale efficiencies of Australian universities through data envelopment analysis. Socio-Economic Planning Sciences, 35(1), 57-80.

12. Aziz, N. A. A., Janor, R. M., \&Mahadi, R. (2013). Comparative departmental efficiency analysis within a university: a DEA approach. Procedia-Social and Behavioral Sciences, 90, 540-548.

13. BanyaK.,\&Elu J. (2001). The World Bank and financing higher education in Sub-Saharan Africa.Higher Education, 42(1), 1-34.

14. Berger, A. N., \& Humphrey, D. B. (1997). Efficiency of financial institutions: International survey and directions for future research. European journal of operational research, 98(2), 175-212.

15. Berger, A. N., Hunter, W. C., \&Timme, S. G. (1993). The efficiency of financial institutions: a review and preview of research past, present and future. Journal of Banking \& Finance, 17(2), 221-249.

16. Caballero, R., Galache, T., Gómez, T., Molina, J., \&Torrico, A. (2004).Budgetary allocations and efficiency in the human resources policy of a university following multiple criteria. Economics of Education Review, 23(1), 67-74.

17. Casu, B., \&Thanassoulis, E. (2006). Evaluating cost efficiency in central administrative services in UK universities. Omega, 34(5), 417-426.

18. Charnes, A., Cooper, W. W., \& Rhodes, E. (1978).Measuring the efficiency of decision making units. European journal of operational research, 2(6), 429-444.

19. Chu, S. F., \& Lim, G. H. (1998). Share performance and profit efficiency of banks in an oligopolistic market: evidence from Singapore. Journal of Multinational Financial Management, 8(2-3), 155-168.

20. Coelli, T. (1996a). A guide to DEAP version 2.1: a data envelopment analysis (computer) program. Centre for Efficiency and Productivity Analysis, University of New England, Australia.

21. Coelli, T. (1996b).Measurement of total factor productivity growth and biases in technological change in Western Australian agriculture. Journal of applied econometrics, 11(1), 77-91.

22. Dickerson, A. P., Geroski, P. A., \& Knight, K. G. (1997). Productivity, efficiency and strike activity. International Review of Applied Economics, 11(1), 119-134.

23. Farrell, M. J. (1957). The measurement of productive efficiency.Journal of the Royal Statistics Society, 120(3), 253-283.

24. Flegg, A. T., Allen, D. O., Field, K., \&Thurlow, T. W. (2004).Measuring the efficiency of British universities: a multi-period data envelopment analysis.Education Economics, 12(3), 231-249.

25. Isik, I., \& Hassan, M. K. (2002).Technical, scale and allocative efficiencies of Turkish banking industry. Journal of Banking \& Finance, 26(4), 719-766.

26. Izadi, H., Johnes, G., Oskrochi, R., \&Crouchley, R. (2002). Stochastic frontier estimation of a CES cost function: the case of higher education in Britain. Economics of Education Review, 21(1), 63-71.

27. Johnes, J. (1996). Performance assessment in higher education in Britain.European Journal of Operational Research, 89(1), 18-33. 
28. Johnes, J. (2006a). Data envelopment analysis and its application to the measurement of efficiency in higher education.Economics of Education Review, 25(3), 273-88.

29. Johnes, J. (2006b). Measuring teaching efficiency in higher education: An application of data envelopment analysis to economics graduates from UK universities 1993.European Journal of Operational Research, 174(1), 443-56.

30. Joumady, O., Ris, C. (2005). Performance in European higher education: A nonparametric production frontier approach. Education Economics, 13(2), 189-205.

31. Kantabutra, S., \& Tang, J. C. (2010).Efficiency analysis of public universities in Thailand.Tertiary Education and Management, 16(1), 15-33.

32. Katharaki, M., \&Katharakis, G. (2010).A comparative assessment of Greek universities' efficiency using quantitative analysis. International journal of educational research, 49(4), 115-128.

33. Kempkes, G., \& Pohl, C. (2008). Do institutions matter for university cost efficiency? Evidence from Germany. CESifo economic studies, 54(2), 177-203.

34. Kirjavainen, T., \&Loikkanent, H. A. (1998). Efficiency differences of Finnish senior secondary schools: an application of DEA and Tobit analysis. Economics of Education Review, 17(4), 377-394.

35. Kounetas, K., Anastasiou, A., Mitropoulos, P., \& Mitropoulos, I. (2011). Departmental efficiency differences within a Greek university: An application of a DEA and Tobit analysis. International Transactions in Operational Research, 18(5), 545-559.

36. Kuah, C. T., \& Wong, K. Y. (2011).Efficiency assessment of universities through data envelopment analysis. Procedia Computer Science, 3, 499-506.

37. Maki, D. R. (1983). Strike activity and productivity growth: evidence from twenty countries. Columbia Journal of World Business.

38. Maki, D. R. (1986). The effect of the cost of strikes on the volume of strike activity. Industrial \&Labor Relations Review, 39(4), 552-563.

39. McMillan, M. L., \&Datta, D. (1998). The relative efficiencies of Canadian universities: a DEA perspective. Canadian Public Policy/Analyse de Politiques, 485-511.

40. National Bureau of Statistics (2012). 2012 Annual Abstract of Statistics. Retrieved from http://www.nigerianstat.gov.ng/pages/NBS\%20eLibrary

41. Nazarko, J., \&Šaparauskas, J. (2013).Application of DEA method in efficiency evaluation of public higher education institutions. Technological and Economic development of Economy, 20(1), 25-44.

42. Pietrzak, M., Pietrzak, P., \&Baran, J. (2016). Efficiency assessment of public higher education with the application of Data Envelopment Analysis: The evidence from Poland. Online Journal of Applied Knowledge Management, 4(2), 59-73.

43. Ramírez-Correa, P., Peña-Vinces, J. C., \& Alfaro-Pérez, J. (2012).Evaluating the efficiency of the higher education system in emerging economies: Empirical evidences from Chilean universities. African Journal of Business Management, 6(4), 1441.

44. Reda, M., \&Isik, I. (2006, December).Efficiency and Productivity Change of Egyptian Commercial Banks 1995-2003.In ERF 13th Annual Conference, Kuwait.

45. Sherman, H. D., \& Gold, F. (1985). Bank branch operating efficiency: Evaluation with data envelopment analysis. Journal of Banking \& Finance, 9(2), 297-315.

46. Tajnikar, M. \&Deebevec, J. (2008).Funding system of full-time higher education and technical system efficiency: Case of the University of Ljubljana.Education Economics, 16(3), 289-303.

47. Taylor, B., \& Harris, G. (2004). Relative efficiency among South African universities: A data envelopment analysis. Higher Education, 47(1), 73-89.

48. TibenszkynéFórika K. (2007). Azoktatáshatékonyságánakmérése a ZMNE 2006-ban végzetthallgatóin DEA módszerhasználatával. Hadmérnök, II. évf., 2. számISSN 1788-1919.

49. Tochkov, K., Nenovsky, N., \&Tochkov, K. (2012).University efficiency and public funding for higher education in Bulgaria. Post-Communist Economies, 24(4), 517-534.

50. Wolszczak-Derlacz, J. and Parteka, A. (2011), Effciency of European public higher education institutions: a two-stage multicountry approach. Scientometrics, 89, 889-917.

51. World Bank (1995). Priorities and strategies for education: A World Bank Review. Washington D.C.

52. Worthington, A. C. (2001). An empirical survey of frontier efficiency measurement techniques in education. Education economics, 9(3), 245-268.

53. Worthington, A. C., \& Lee, B. L. (2008). Efficiency, technology and productivity change in Australian universities, 1998-2003. Economics of education review, 27(3), 285-298. 